\title{
Perubahan Sosial dalam Perkembangan Pariwisata Desa Cibodas Kecamatan Lembang
}

\author{
Hilman Nugraha ${ }^{1}$, Dasim Budimansyah ${ }^{2}$, Mirna Nur Alia $A^{3}$ \\ ${ }^{1}$ Mahasiswa Program Magister Pendidikan Sosiologi, Sekolah Pascasarjana UPI \\ 2Dosen Program Studi Pendidikan Sosiologi \\ ${ }^{3}$ Dosen Program Studi Pendidikan Sosiologi
}

\begin{abstract}
ABSTRAK
Perkembangan parwisata mengakibatkan perubahan sosial pada masyarakat Desa Cibodas. Tujuan penelitian adalah untuk mengetahui, mendeskrifsikan dan menganalisis perubahan sosial yang terjadi pada anggota-anggota masyarakat di Desa Cibodas Kecamatan Lembang. Penelitian ini menggunakan pendekatan kualitatif dan metode studi kasus. Hasil penelitian menunjukan bahwa adanya perkembangan pariwisata diterima baik oleh warga masyarakat di Desa Cibodas. Faktor-faktor yang mempengaruhi perubahan sosial yaitu adanya penerimaan terhadap unsur-unsur yang baru, menerima adanya akulturasi, adanya migrasi, menerima adanya perubahan kebiasaan hidup dari tradisional ke semi modern,adanya sikap menghargai hasil karya orang lain dan keinginan untuk maju.
\end{abstract}

Kata kunci: Perubahan sosial, Pariwisata, Masyarakat

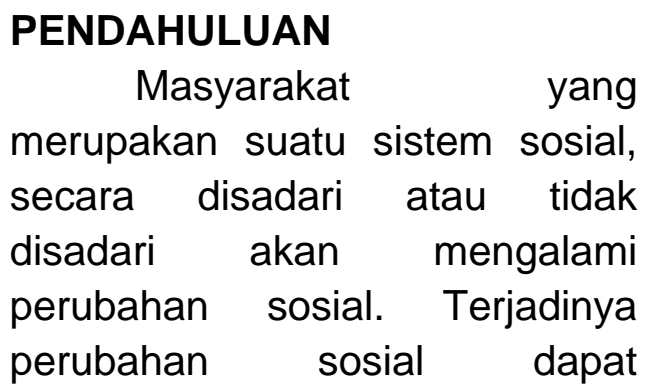

disebabkan oleh beberapa faktor, salah satunya karena adanya penemuan-penemuan baru, hasrat ingin maju, dan lain-lain. Adanya perkembangan pariwisata, merupakan salah satu faktor penyebab yang akan

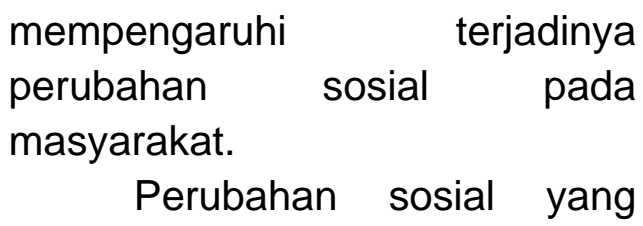
terjadi dalam masyarakat tidak selamanya akan berdampak kepada kemajuan, namun dampak yang ditimbulkan dapat mengakibatkan kemunduran. Masyarakat memandang sebuah kemajuan yang terjadi di lingkungannya merupakan sebuah keberhasilan. Namun apabila kita menelaahnya lebih 
dalam lagi, perubahan tersebut dapat berbanding terbalik dengan sistem sosial yang ikut mengalami perubahan yang dapat dirasakan oleh anggotaanggota masyarakatnya. Sistem sosial yang ikut mengalami perubahan, salah satu contohnya akan membentuk anggotaanggota masyarakat yang individualistis.

Berkaitan dengan yang telah dipaparkan di atas, menurut Nazsir (2008, hlm. 157) mengemukakan bahwa "Masyarakat sebagai suatu sistem tentu dalam perwujudannya, senantiasa mengalami perubahan dapat berupa kemajuan atau kemunduran, luas atau terbatas, cepat atau lambatnya". Sehingga dapat dikatakan bahwa semua anggota-anggota masyarakat akan mengalami perubahan selama hidunya. Perubahan tersebut dapat kearah kemajuan (progres) ataupun perubahan tersebut dapat terjadi ke arah kemunduran.

Berbagai permasalahan yang diakibatkan karena perkembangan pariwisata menjadikan perubahanperubahan yang terjadi di masyarakat.

Perubahan yang diakibatkan oleh perkembangan pariwisata dapat dikategorikan sebagi perubahan yang terencana ataupun perubahan yang tidak direncanakan.

Perkembangan pariwisata dapat menimbulkan perubahan yang berdampak positif dan negatif. Namun, hal yang harus di pikirkan dan diperhatikan adalah perubahan yang menimbulkan dampak negatif. Fakta-fakta yang muncul dari perkembangan pebangunan pariwisata yang berdampak kepada perubahan sosial masyarakat. Berbagai masalah timbul dan bermunculan sebagai efek dari perkembangan pariwisata yang mengakibatkan perubahan sosial di masyarakat seperti perubahan gaya hidup, pergaulan, sikap atau perilaku yang ditunjukan oleh anggotaanggota masyarakat telah keluar dari nilai ataupun norma yang berlaku.

Masyarakat yang tinggal di pedesaan umumnya bermata pencaharian sebagai petani. Pertemuan yang terjadi antara masyarakat agraris dan sektor kepariwisataan akan melahirkan perubahan-perubahan yang relatif homogen menuju yang relatif kompleks, baik itu dalam pola tingkahkah laku, pranata sosial ataupun sistem sosial dalam sebuah masyarakat. Pertemuan dua bentuk kebudayaan tersebut akan melahirkan kebudayaan baru, baik pada pihak penerima 
ataupun kepada pihak yang akan memberikan pengaruh.

Perubahan sosial yang terjadi dalam kehidupan berasyarakat dapat disebabkan oleh beberapa hal, salah satunya dikarenaka rasa tidak puas yang ada pada diri seorang manusia. Sebagaimana yang kemukakan oleh Gillin dan Gillin dalam Setiadi dan Kolip(2011, hlm. 610) , bahwa:

Perubahan sosial sebagai, suatu variasi dari cara-cara hidup yang telah diterima, yang disebabkan baik karena perubahan kondisi geografis, kebudayan materil, komposisi penduduk, ideology maupun karena adanya difusi maupun penemuanpenemuan baru dalam masyarakat tersebut.

\section{GAMBARAN PERKEMBANGAN PARIWISATA DESA CIBODAS}

Masyarakat mengatakan setuju dengan adanya perkembangan pariwisata di Desanya. Dikarenakan dengan masuknya pariwisata, akan membantu dan dapat mensejahtrakan masyarakat sekitar. Adanya pariwisata dapat menyediakan lapangan pekerjaan, sehingga dapat meningkatkan tingkat ekonomi penduduk.

Menurut hasil observasi peneliti menemukan keadaan lingkungan dan keadaan sosial masyarakat Desa Cibodas yang tertata dengan baik, ketertiban warga masyarakat, keamanan yang terkendali, penduduk yang ramah dan masyarakat masih memiliki rasa kegotong-royongan yang kuat. Demikian pula keadaan bangunan rumah penduduk yang berdiri kokoh dan bagus, menandakan bahwa masyarakat Desa Cibodas telah sejahtera. Meskipun masih terlihat adanya sedikit masalah yang berkaitan dengan lingkungan, misalnya gundunkan sampah yang berserakan di sepanjang jalan di Desa Cibodas. Keadaan sosial masyarakat yang lebih memperhatikan pemenuhan kebutuhan ekonomi. Hal itu tampak dengan keseriusan warga sekitar dalam melakukan pekerjaannya, sehingga tidak sedikit warga yang beralih profesi yang semula menjadi buruh tani, sekarang menjadi tenaga kerja di objek pariwisata atau kegiatankegiatan lain yang berkaitan dengan kepariwisataan seperti menjadi pengrajin barang-barang cendramata, menjadi pedagang hasil bumi dan pedagang makanan yang lainnya.

Temuan peneliti berkaitan dengan pendapat dari Suwantoro (2004, hlm 26-27) mengenai manfaat pembangunan pariwisata nasional, yaitu dalam 
"bidang ekonomi meningkatkan kesempatan kerja dan berusaha, baik secara langsung maupun tidak langsung dan meningkatkan dan memeratakan pendapatan masyarakat melalui belanja wisatawan baik langsung maupun tidak langsung melalui dampak berganda (multiflier effect)".

Faktor-faktor

yang

mempengaruhi perubahan sosial yang terjadi di Desa Cibodas Kecamatan Lembang, dalam berbagai segi kehidupannya dapat dilihat dari; pertama, adanya penerimaan terhadap unsur-unsur yang baru, seperti beralihnya mata pencaharian dari petani menjadi pelayan jasa pariwisata, dari petani menjadi pelaku industri kreatif, dari petani menjadi pedagang. Kedua, menerima adanya akulturasi yaitu dapatberbaur dengan masyarakat yang datang dari luar (wisatawan). Ketiga, adanya migrasi dari kota ke Desa. Keempat, menerima adanya perubahan kebiasaan hidup dari tradisional ke semi modern. Kelima, adanya sikap menghargai hasil karya orang lain dan keinginan untuk maju Senada dengan pemaparan di atas, menurut Rosana modernisasi dan perubahan sosial merupakan dua hal yang saling berkaitan. Modernisasi pada hakikatnya mencakup bidang-bidang yang sangat banyak, bidang mana yang akan diutamakan oleh suatu masyarakat tergantung dari kebijakan penguasa yang memimpin masyarakat tersebut. Modernisasi hampir pasti pada awalnya akan mengalami disorganisasi dalam masyarakat, apalagi yang menyangkut nilainilai dan norma-norma dalam masyarakat, dimana masyarakat yang bersangkutan belum siap untuk berubah, karena perubahannya begitu cepat serta tidak mengenal istirahat. Hal tersebut akan mengakibatkan disorganisasi yang terus menerus, karena masyarakat tidak pernah sempat untuk mengadakan reorganisasi.

Menurut Soekanto (2007, hlm. 287) mengemukakan faktor pendorong terjadinya perubahan sosial dapat disebutkan, antara lain:

1) Kontak dengan kebudayaan lain

2) Sistem pendidikan yang maju

3) Sikap menghargai hasil karya orang lain dan keinginan-keinginan untuk maju

4) Toleransi terhadap perbuatan-perbuatan yang menyimpang (deviation) yang bukan merupakan delik

5) Sistem terbuka dalam lapisan masyarakat (open stratification) 
6) Adanya penduduk yang heterogen

7) Ketidakpuasan masyarakat terhadap bidang-bidang kehidupan tertentu

8) Orientasi ke masa depan

9) Nilai meningkatkan taraf hidup

Apabila dikaitkan dengan pendapat yang dikemukakan oleh Soekanto mengenai faktor pendorong dan penghambat terjadinya perubahan sosial, yang terjadi di Desa Cibodas perubahannya disebabkan karena faktor adanya kontak dengan kebudayaan lain dan faktor pendorong mengenai sistem terbuka dari lapisan masyarakat (open stratification), penduduk yang heterogen dan adanya nilai untuk meningkatkan taraf hidup.

$$
\text { Hasil }
$$

penelitian

menemukan bahwasannya masyarakat setempat mengalami kontak dengan wisatawan meskipun hanya segelintir orang, karena wisatawan juga ingin mengetahui karakteristik yang unik di Desa Cibodas maka wisatawan akan berinterkasi dan melakukan kontak sosial dengan masyarakat setempat. Secara tidak langsung masyarakat melihat juga karakteristik dari wisatawan, sehingga adanya sebuah transformasi nilai sosial antara warga dengan wisatawan.
Perkembangan pariwisata di Desa Cibodas yang semakin maju selain menimbulkan dampak yang positif juga menimbulkan dampak negatif terhadap terjadinya perubahan sosial di masyarakat. Berdasarkan observasi yang dilakukan, dampak-dampak positif dapat terlihat dari aspekaspek sebagai berikut; Pertama, tingkat kesejahtraan masyarakat semakin meningkat. Kedua, warga masyarakat dapat mengikuti perkembangan ilmu pengetahuan dan teknologi. Ketiga, lapangan pekerjaan semakin kompetitif. Keempat, fasilitas umum lebih tersedia. Kelima, pemasaran hasil panen pertanian dapat dijual di tempat pariwisata

Selain dampak positif yang telah disebutkan di atas, peneliti juga menemukan pengaruh negatif dari perkembangan kepariwisataan di Desa Cibodas di antaranya; Pertama, prilaku masyarakat semakin konsumtif. Kedua, kesenjangan sosial semakin tinggi. Ketiga, nilai-nilai tradisional semakin terkikis. Keempat, keadaan lingkungan yang menjadi rusak. Kelima, lahan pertanian semakin menyempit, dan lain-lain.

Perubahan sosial akan mempengaruhi berbagai aspek kehidupan, salah satunya dapat disebabkan oleh perkembangan 
pariwisata. Observasi yang dilakukan untuk melihat perkembangan pariwisata mempengaruhi perubahan sosial, diantaranya; Pertama, yaitu dari prilaku masyarakat menjadi konsumtif. Kedua, yaitu munculnya sikap individualistis. Ketiga, yaitu gotong royong warga masyarakatnya yang telah berubah. Keempat, yaitu sistem sosial telah mengalami perubahan. Kelima, yaitu terjadinya stratifikasi sosial dan kesenjangan sosial. Keenam, yaitu melemahnya nilai-nilai sosial.

\section{PENUTUP}

Masyarakat setempat setuju dan mendukung adanya perkembangan pariwisata di desanya. Hal tersebut merupakan salah satu faktor yang menyebabkan perkembangan pariwisata di Desa Cibodas terus meningkat, selain ditunjang dengan udara yang sejuk dan alam yang eksotik.

\section{Faktor-faktor}

yang mepengaruhi perubahan sosial diantaranya, yaitu adanya penerimaan terhadap unsur yang baru, adanya migrasi dari kota ke desa, adanya perubahan kebiasaan hidup dari tradisional ke semi modern, adanya sikap menghargai hasil karya orang lain dan keinginan untuk maju.
Dampak postif yang ditimbulkan adalah tingkat kesejahtraan masyarakat semakin meningkat, warga masyarakat dapat mengikuti perkembangan ilmu pengetahuan dan teknologi, lapangan pekerjaan semakin kompetitif, fasilitas umum lebih tersedia, pemasaran hasil panen pertanian dapat dijual di tempat pariwisata.

Sedangkan dampak negatifnya adalah konsumtif, kesenjangan sosial, nilai-nilai tradisional semakin terkikis, lingkungan menjadi rusak, lahan pertanian semakin menyempit.

Perkembangan pariwisata yang mempengaruhi perubahan sosial adalah prilaku masyarakat menjadi konsumtif, munculnya sikap individualistis, gotong royong warga masyarakatnya yang telah berubah, sistem sosial telah mengalami perubahan, terjadinya stratifikasi sosial atau kesenjangan sosial dan melemahnya nilai-nilai sosial.

\section{DAFTAR RUJUKAN}

Nazsir, R. Nasrullah. (2008). Sosiologi Kajian Lengkap Konsep dan Teori Sosiologi Sebagai IImu Sosial. Bandung : Widya Padjadjaran Setiadi dan Kolip. (2011). Pengantar Sosiologi: Pemahaman Fakta dan Gejala Permasalahan Sosial: Teori, Aplikasi, dan Pemecahannya. Jakarta: 
Kencana Prenada Media Suwantoro, Gamal (2004). Dasar-

Group Dasar Pariwisata.

Soekanto, Soerjono. (2007). Yogyakarta: ANDI

Sosiologi: Suatu Pengantar. Yogyakarta

Jakarta: PT RajaGrafindo

Persada 